Proceedings of the 24th International Symposium "The Environment and the Industry" (E-SIMI 2021), 24 September 2021, online event

\title{
Geochemical evaluation of soils, surface and groundwater from natural protected areas from Romania. Case studies.
}

\author{
BOGDAN ADRIAN STANESCU*, ADRIANA CUCIUREANU, GINA ALINA CATRINA, \\ GEORGIANA CERNICA, LIDIA KIM
}

National Research and Development Institute for Industrial Ecology - ECOIND, 57-73 Drumul Podul Dambovitei Street, 060652, Bucharest, Romania

*Corresponding author: stanescubogdan2@gmail.com

$\begin{array}{lll}\text { Received: } & \text { Accepted: } & \text { Published: } \\ \text { 20.09.2021 } & 10.12 .2021 & 17.12 .2021\end{array}$

\begin{abstract}
The purpose of this article was to present an assessment of the soil and water quality in some protected areas from Romania in order to establish a series of geochemical thresholds on a spatial and temporal scale. The activities and results presented in this article are based on extensive monitoring, being stage results because the monitoring activities will continue, the project is ongoing. Two protected areas, Cheile Nerei -Beusnita National Park and Piatra Craiului National Park were selected. Surface water, groundwater samples, and soil samples were collected in 2019, respectively 2021 from 16 sampling sites situated in both locations. For each sample, twenty quality parameters/indicators were analyzed and the values were compared with in-force legislations. For Arsenic, Copper, and Nitrates parameters were plotted the distribution of the values in each site. In future monitoring activities, the evolution of the parameters will be followed.
\end{abstract}

Keywords: geochemical thresholds, assessment, protected areas, soil, water

\section{INTRODUCTION}

Numerous studies are dedicated to evaluating the heavy metals concentrations in soil and water in correlation with geological factors for the spatial highlighting of the concentrations distribution over large geographical areas [1-6].

There are concerns for the elaboration of indexing methods of pollution, respectively, quantifying the environmental risk for an analyzed chemical element or several elements. Moreover, there are geochemical maps that illustrate the environmental risk index, illustrated concentrate graphs that are located above the allowed levels, in relation to the specific legislation, respectively the compliance for the agricultural use area or for the residential areas [7].

Other studies are focused on finding geochemical thresholds using $\mathrm{C}-\mathrm{N}$ fractal analysis models, making maps of geochemical anomalies and delimiting probable abnormal sites. The spatial distribution of $\mathrm{Mn}, \mathrm{Cu}, \mathrm{Co}, \mathrm{Pb}$ and $\mathrm{Zn}$ anomalies was correlated with the $\mathrm{Mn}$ and $\mathrm{Cu}$ mineralization sites, while $\mathrm{Fe}$ and $\mathrm{Cr}$ were consistent with magmatic rock distributions [8].

There are concerns to establish some regionalization criteria by highlighting the biogenic cycles of chemical elements, respectively, the links of the biogeochemical food chain, starting from rocks pedogenesis and to human. One of the criteria is that of the concentrated threshold, starting from the premise that the organism regulates its metabolism within the limits of the concentration of chemical elements between the upper and lower thresholds [9]. 
Modern methods of analyzing the spatial distribution of rock deposits on a regional scale using a cartographic database in geographic information systems (GIS) systems can reveal several relationships between petrographic activity and environmental variables [10-12].

Moreover, the evaluation of groundwater quality is also important to identify potential pollution sources $[13,14]$.

The indices used in the evaluation of water quality combine the results of several water quality parameters, resulting in a number without a unit of measurement, but which, although dimensionless, provides concrete information about water quality [15-17].

Structuring the data on the quality of the water factor in databases is a very important aspect, especially when it comes to a large volume of information [18].

The purpose of the present study was to highlight the relevant aspects regarding the quality of environmental factors in the areas chosen as case studies to obtain a series of geochemical thresholds finally.

\section{EXPERIMENTAL PART}

The context of the report regards the investigation and assessment of the soil quality and water in 2 protected areas in Romania, Cheile Nerei-Beusnita National Park and Piatra Craiului National Park. Figure 1 presents the location of the selected sites.

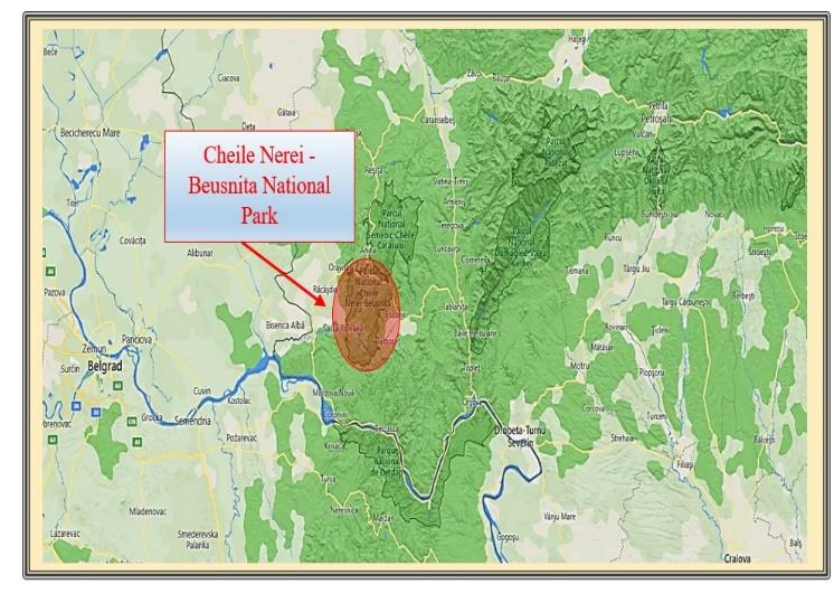

a) Cheile Nerei -Beusnita National Park

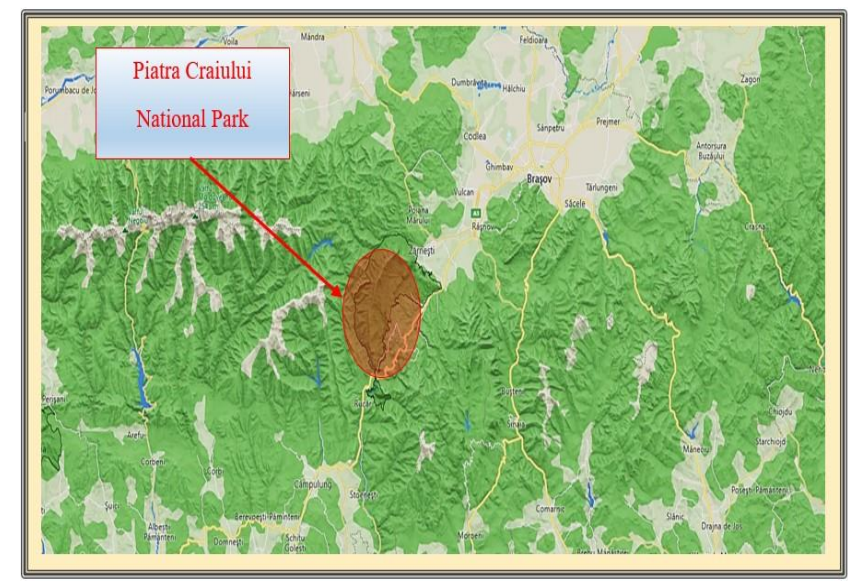

b) Piatra Craiului National Park

Fig. 1. Location of the site in the south west part of Romania (a) and in the central part of Carpathians (b)

Cheile Nerei - Beusnita National Park, in Caras Severin County, is located in the southwestern part of the county, being crossed by the DN57B national road that connects Oravita town with Bozovici commune. The national park is a mountainous area with many limestone cliffs, with specific karst relief (caves, gorges, waterfalls).

The experimental field was established considering the main access roads and was dimensioned at 10 sampling points (soil, surface water and groundwater from springs) located inside the natural park and in its vicinity.

The location in the area of the experimental field is in figure 2a. For the Cheile Nerei - Beusnita National Park area, it is distinguished that during the investigated period (May 2021), the precipitations ensured normal flows, respectively a good supply of the hydrographic network (Nera rivers with its tributaries and Minis river with its tributaries).

Piatra Craiului National Park, in Brasov and Arges Counties is located in the Southern Carpathians, including the Piatra Craiului Ridge in its entirety and spaces in the neighboring corridors, RucarBran and Rucar-Zarnesti. The karst relief gives a special note to this natural site.

The experimental field was established at six soil and water sampling points (surface water courses and groundwater -springs) presented in figure $2 \mathrm{~b}$. 
The soil samples were collected with an Edelman-type pedological drill kit and the geographical coordinates of the sampling points were recorded with Garmin GPS, model type Montana 610.

The samples were labeled, adequately preserved, transported to the laboratories of National Research and Development Institute for Industrial Ecology, Bucharest headquarter, in the shortest possible time to perform analytical laboratory tests.

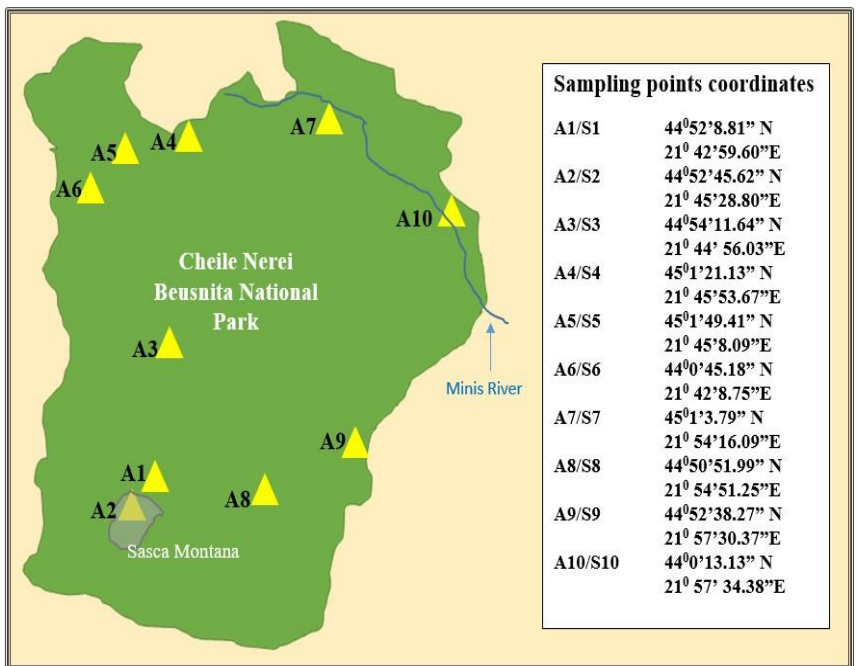

a)

Cheile Nerei -Beusnita National Park

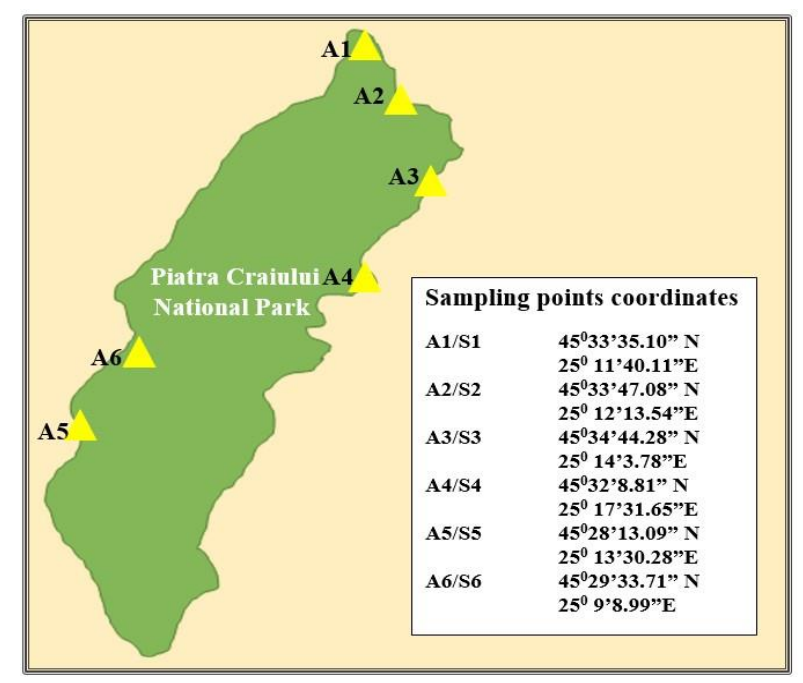

b) Piatra Craiului National Park

Fig. 2. Location of the sampling points and GPS coordinates

The quality indicators determined for the soil environment factor were as follows: $\mathrm{pH}$, humus, Kjeldahl nitrogen, iron, arsenic, barium, cadmium, cobalt, total chromium, copper, manganese, molybdenum, nickel, lead, selenium, antimony, vanadium, zinc, and potassium. The quality indicators determined for the water factor environment (surface water and groundwater) were the following: $\mathrm{pH}$, iron, aluminum, ammonium, nitrite, nitrate, cadmium, total chromium, copper, manganese, mercury, nickel, selenium, antimony, lead, zinc, COD, BOD, calcium, magnesium, and sodium.

\section{RESULTS AND DISCUSSIONS}

For each soil sample taken, the quality indicators were analyzed, and standardized test methods were used. For metallic elements, the analytical determination was used an ICP-MS 7900 Agilent equipment, model G8403A.

The interpretation of the soil results was performed by comparison with the reference values from the specific legislation, respectively at the reference values for the traces of chemicals in the soil at sensitive land use, practically the most severe quality conditions established for land use [19].

For the interpretation of the results for the water samples, the threshold values and limits related to the ecological status classes of the water bodies from the in force national legislation were used [20, 21].

The analysis data were compared (Spring 2021 versus Summer 2019) and the registered concentrations of some pollutants were ploted in the figures 3 to 5 .

For example, the Arsenic values detected at Cheile Nerei-Beusnita National Park in both investigation campaigns were situated in same range, the lowest value being recorded in 2021 Spring. All Arsenic registered values were situated below the normal value (NV) of $5 \mathrm{mg} / \mathrm{kg}$ dry weight (d.w.) according to in force legislation [19].

Figure 3 a presents the variation of the average values obtained in the 2 reference periods. 


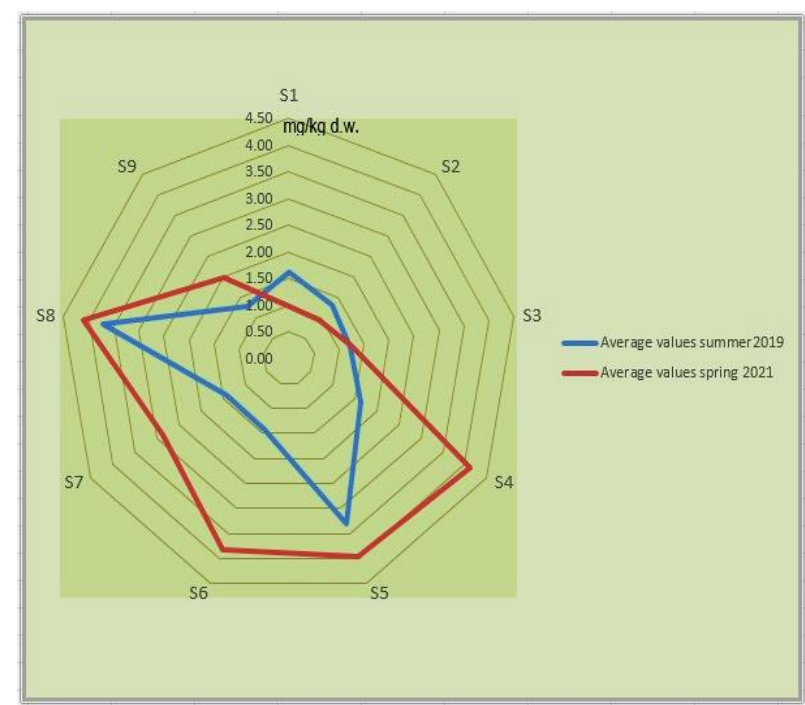

a) Cheile Nerei-Beusnita National Park

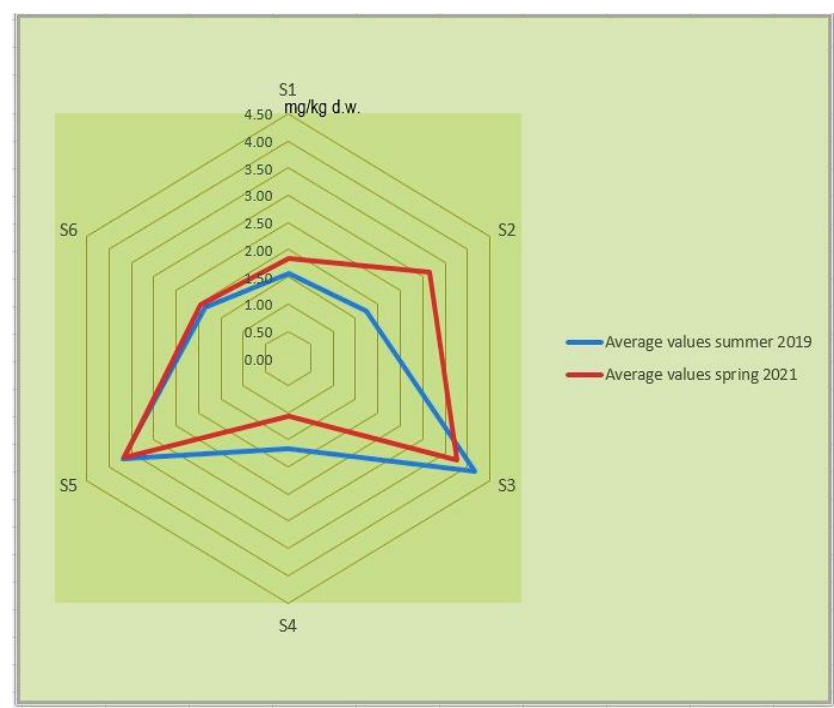

b) Piatra Craiului National Park

Fig. 3. The variation of the average values of Arsenic in soil - Campaign Summer 2019 versus Campaign Spring 2021

The highest average values were recorded in the spring 2021 campaign compared to the summer of 2019 , in the sampling points S4, S5, S6, S8, and S9.

It was observed small variations of some values between the soil samples from the same investigation campaign, but the differences were important from one reference period to another, respectively higher values were registered in 2021 compared to 2019.

The positive aspect was that the recorded values did not exceed the normal values, but it is important to monitor the trend, respectively, if these values will be reached in the future.

In Piatra Craiului National Park (figure 3b) the highest average values of Arsenic was found in S1 and S2 points in 2021 spring campaign compared to 2019 summer, while the lowest values were reported in S3 and S4. The samples collected from S5 and S6 points were situated in the same range in both campaigns.

Some As values in soil were recorded small variation variations between the samples within the same investigation campaign. However, the differences were important from one reference period to another, respectively both higher values were registered in 2021, compared to 2019, but also higher values in 2019 in certain sampling points. The positive aspect was that the recorded values did not exceed the normal values, but it is important to monitor the tendency towards reaching the normal values in the future.

The values of the Copper quality indicator for Cheile Nerei Beusnita National Park experimental field are shown in figure 4 a.

In the 2019 campaign were registered lower Copper concentrations compared to 2021. All the registered values do not exceed NV, respectively $20 \mathrm{mg} / \mathrm{kg} \mathrm{d} . \mathrm{w}$. However, the maximum values from 2021 investigation campaign tended to reach the normal value. Subsequent monitoring will look at whether high values will be obtained and whether there will be a growth trend.

The variation of the average values of Copper presented in figure $4 \mathrm{a}$ for Cheile Nerei-Beusnita National Park highlights higher values in 2021 (with a few exceptions such as: S1, S6, and S7), but without large amplitudes between the 2 reference periods. The Copper concentrations recorded small variations of the values within the same campaign, with the exception of the S9 soil sample from 2019 campaign.

Regarding Piatra Craiului National Park (figure 4b), lower values of Copper were recorded in 2019 compared to 2021. The values recorded in both campaigns were situated above NV in the soil, but well below the alert threshold for sensitive land use.

Future monitoring is necessary to highlight the tendency to maintain, decrease or increase the Copper concentration. 


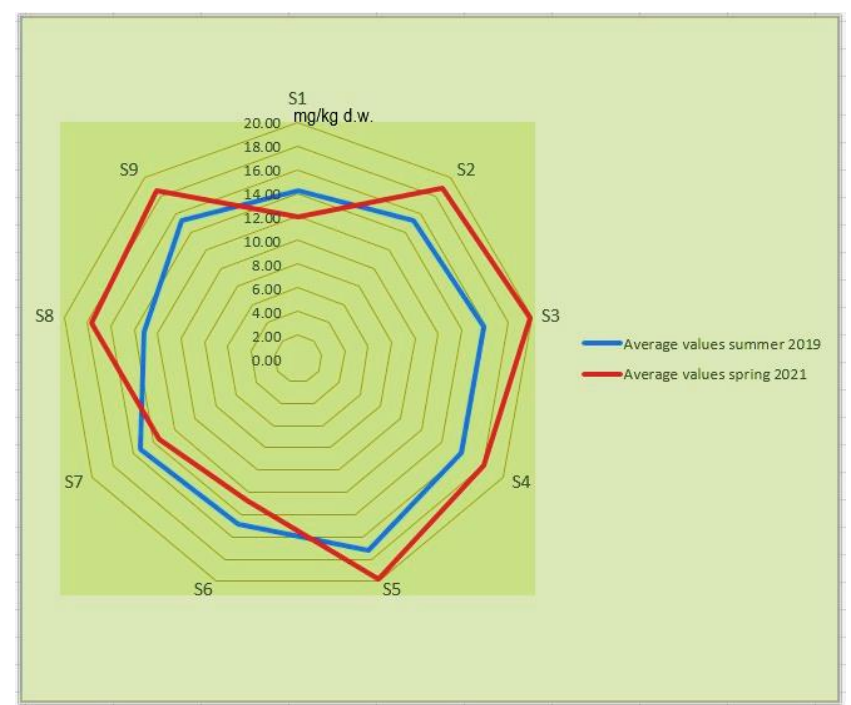

a) Cheile Nerei-Beusnita National Park

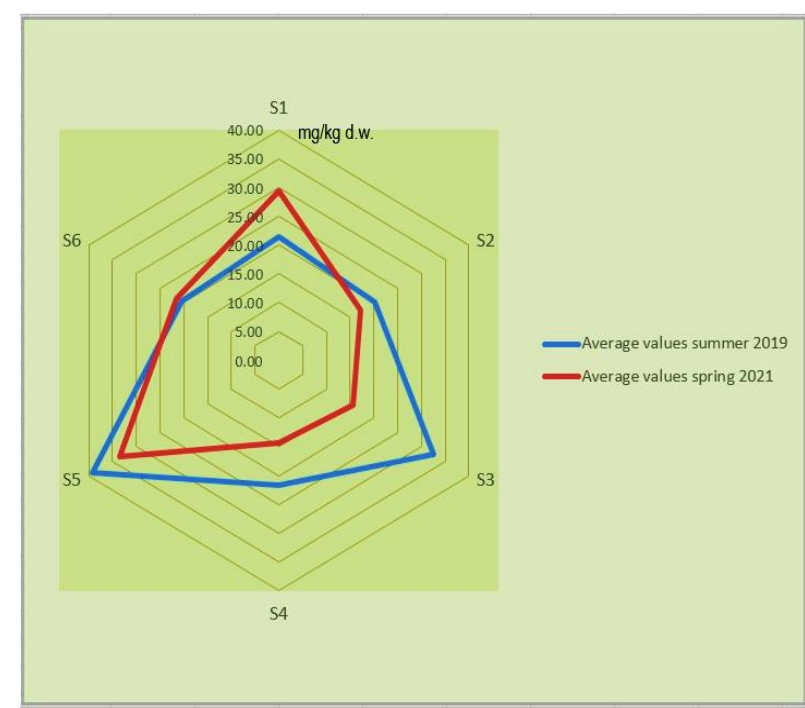

b) Piatra Craiului National Park

Fig. 4. The variation of the average values of Copper in soil - Campaign Summer 2019 versus Campaign Spring 2021

In the characterization of Cheile Nerei Beusnita National Park, a particularly interesting was recorded regarding the anthropogenic pressures manifested in the vicinity of the protected natural area concerning the surface water environmental factor. In figure 5 is shown the variation of the Nitrates quality indicator in both analyzed periods.

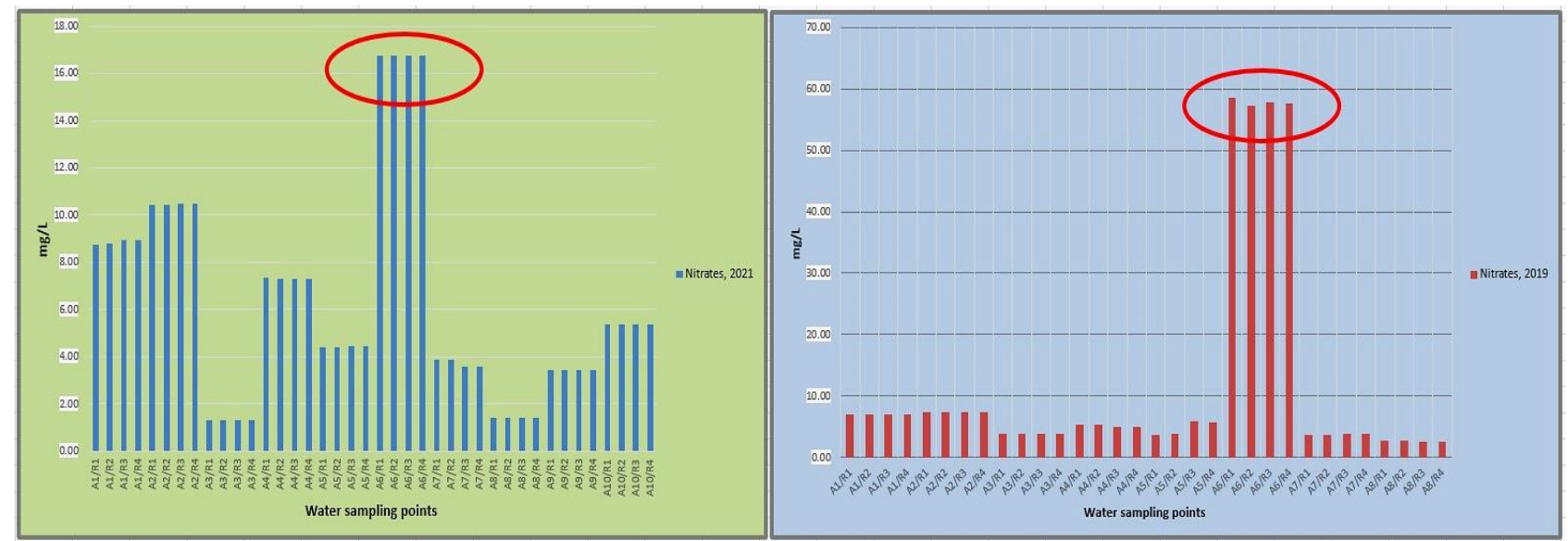

Fig. 5. The variation of the Nitrates values in water samples collected from Cheile Nerei - Beusnita National Park, Campaign Summer 2019 versus Campaign Spring 2021

Variations in the average values of Nitrates concentrations between $6.30 \mathrm{mg} / \mathrm{L}$ in 2021 and 11.51 $\mathrm{mg} / \mathrm{L}$ in 2019 were obtained. The maximum concentration was recorded at point A6 in the spring campaign of $2019(58.47 \mathrm{mg} / \mathrm{L})$. In 2021 at the same sampling point were recorded high concentrations above $50 \mathrm{mg} / \mathrm{L}$. This sampling point is located in Ciclova Montana locality, and the water collected was a groundwater sampled from a street fountain under the influence of anthropogenic factors that occur outside the protected area. The distance from the Cheile Nerei Beusnita National Park is relatively small, less than $10 \mathrm{~km}$.

\section{CONCLUSIONS}

The study was highlighted some evolutionary aspects, correlated with the influencing factors, especially the anthropic ones that have a negative impact on the quality of the environmental factors.

Obtaining data/information was done by seasonal evaluation of the quality of soil and water environmental factors. The results from field research were processed, correlated, and interpreted 
according to the threshold values from the legislation specific to the evaluation of the analyzed environmental factors. Solid data were obtained for the soil and water environmental factors that describe the environmental status for the studied areas and will later serve to establish geochemical threshold values for both analyzed factors.

A notable result of the project was the experimental model dedicated to the geochemical study of protected natural areas.

In addition, some trends have emerged that must be monitored in the next period because the research project is in progress. Future studies will create, update and strengthen the georeferenced database in terms of the integrated data flow.

\section{ACKNOWLEDGEMENTS}

The scientific work was founded by Ministry of Research, Innovation and Digitalization of Romania through "Nucleu” Program contract 20N/2019, Project PN 19040203.

\section{REFERENCES}

[1] CABRAL PINTO, M.M.S., FERREIRA DA SILVA, E., SILVA, M.M.V.G., MELOGONCALVES, P., J. Afr. Earth. Sci., 2015, 101, p. 162.

[2] SALOMAO, G.N., FIGUEIREDO, M.A., DALL'AGNOL, R., SAHOO, P.K. , DE MEDEIROS FILHO, C.A., DA COSTA, M.F., ANGELICA, R.S., J. Afr. Eart. Sci., 2019, 92, p. 151.

[3] SKORDAS, K., KELEPERTSIS, A., Environ. Geol., 2005, 48, no. 4-5, p.615.

[4] BERG, T., ROYSET, O., STEINNES, E., Atmos. Environ., 1994, 28, no. 21, p. 3519.

[5] DE CARITAT, P., REIMANN, C., BASTRAKOV, E., BOWBRIDGE, D., BOYLE, P., BRIGGS, S., BROWN, D., BROWN, M., BROWNLIE, K., BURROWS, P., BURTON, G., BYASS, J., Earth Planet. Sci. Lett., 2012, 319, p. 269.

[6] VODYANITSKII, YU. N., Eurasian Soil Sci., 2012, 45, no. 3, p. 321.

[7] GUSSO-CHOUERI, P.K., CHOUERI, R.B., DE ARAÚJO, G.S., CRUZ, A.C.F., STREMEL, T., CAMPOS, S., DE SOUSA ABESSA, D.M., RIBEIRO, C.A.O.E., Environ. Sci. Pollut. Res., 2015, 22, p. 18047.

[8] KOVALSKY, V.V., Philos. Trans. R. Soc. Lond. B Biol. Sci., 1979, 288, no. 1026, https://doi.org/10.1098/rstb.1979.0100.

[9] HOSSAM, A.H., AHMED, M.E.M., KHALIL, I.K., Geochem. Explor. Environ. Anal., 2021, 21, no. 3, https://doi.org/10.1144/geochem2021-031.

[10] FORTIN, MJ., Encyclopedia of GIS, 2017, https://doi.org/10.1007/978-3-319-178851 1640.

[11] GENELETTI, D., VAN DUREN, I., Landsc. Urban Plan, 2008, 85, p. 97.

[12] TEZEL, D., INAM, S., KOCAMAN, S., ISPRS Int. J. Geoinf., 2020, 9, 91, https://doi.org/10.3390/ijgi9020091.

[13] SUTHAR, S., BISHNOI, P., SINGH, S., MUTIYAR, P.K., NEMA, A.K, PATIL NS, J. Hazard Mat., 2009, 171, p. 189.

[14] SINGH, P., CHATURVEDI, R.K, MISHRA, A., KUMARI, L., SINGH, R., PAL, D.B., Environ. Monit. Assess., 2015, 187, p.1.

[15] DIPPONG, T., MIHALI, C., HOAGHIA, M.A., CICAL, E., COSMA, A., Ecotox. Environ. Safe., 2019, 168, p. 88.

[16] MUKATE, S., WAGH, V., PANASKAR, D., JACOBS, J.A., SAWANT, A., Ecol. Indic., 2019, 101, p. 348.

[17] CHANG, N., LUO, L., WANG, X.C., SONG, J., HAN, J., AO, D., Sci. Total Environ., 2020, 735, https://doi.org/10.1016/j.scitotenv.2020.139351.

[18] NEIDONI, D.G., NICORESCU V., ANDRES L., NEGREA, S.C., DIACONU, L.A., Rom. J. Ecol. Environ. Chem., 2021, 3, no. 1, p. 29, https://doi.org/10.21698/rjeec.2021.104.

[19] ORDER 756/1997 for approval Regulations on environmental pollution assessment with subsequent amendments and completions, http://legislatie.just.ro/Public/DetaliiDocument/13572, [21.09.2021]. 
[20] ORDER 161/2006 for the approval of the Norm regarding the classification of surface water quality in order to establish the ecological status of water bodies, http://legislatie.just.ro/Public/DetaliiDocumentAfis/72574, [21.09.2021].

[21] ORDER 621/2014 regarding the approval of the threshold values for groundwater in Romania, http://legislatie.just.ro/Public/DetaliiDocumentAfis/159990, [21.09.2021].

Citation: Stanescu, B.A., Cuciureanu, A., Catrina, G.A.., Cernica, G., Kim, L., Geochemical evaluation of soils, surface and groundwater from natural protected areas from Romania. Case studies., Rom. J. Ecol. Environ. Chem., 2021, 3, no.2, pp. 71-77.

(C) 2021 by the authors. This article is an open access article distributed under the terms and conditions of the Creative Commons Attribution (CC BY) license (http://creativecommons.Org/licenses/by/4.0/). 